\title{
Effects of temperature, heating time and particle size on values of rumen undegradable protein of roasted soybean
}

\author{
H. Rafiee-Yarandi , M. Alikhani, G.R. Ghorbani \& A. Sadeghi-Sefidmazgi \\ Department of Animal Sciences, College of Agriculture, Isfahan University of Technology, Isfahan, Iran
}

(Received 11 June 2015; Accepted 15 January 2016; First published online 30 May 2016)

\author{
Copyright resides with the authors in terms of the Creative Commons Attribution 2.5 South African Licence. \\ See: http://creativecommons.org/licenses/by/2.5/za \\ Condition of use: The user may copy, distribute, transmit and adapt the work, but must recognise the authors and the South African Journal \\ of Animal Science.
}

\begin{abstract}
Roasted soybeans are commonly used in diets for dairy cows, but the processing conditions of roasted soybean and their effects on rumen undegradable protein (RUP) have not been fully understood. In this study, the effect of the processing of roasted soybean on RUP was examined through a factorial arrangement of treatments. The effects of roasting temperature $\left(115{ }^{\circ} \mathrm{C}, 130^{\circ} \mathrm{C}\right.$ and $\left.145^{\circ} \mathrm{C}\right)$, time of roasting (5, 10 and $15 \mathrm{~min}$ ) and particle size of soybean (whole, coarse and fine) on the protein fractions of roasted soybean were analysed with the Cornell Net Carbohydrate and Protein System (CNCPS) and protein dispersibility index (PDI) methods. The whole, coarsely ground and finely ground soybean had mean particle sizes of $5.30 \mathrm{~mm}, 1.15 \mathrm{~mm}$ and $1.05 \mathrm{~mm}$. The proportion of soluble protein was reduced with increasing temperature and time of roasting. The true protein with intermediate rates of degradation decreased with escalating temperatures, but increased when the time was raised and the particle size reduced. Also, the true protein level with slow rates of degradation was raised with increasing temperature and heating time, but reduced when decreasing the particle size. The undegradable true protein level, on the other hand, was increased by decreasing the particle size. The results of CNCPS and PDI revealed that the recommended method would be to use soybeans with a particle size of $1.15 \mathrm{~mm}$, and to roast them at $115^{\circ} \mathrm{C}$ for 10 minutes. Furthermore, the results showed that different methods of processing used in soybean roasting could strongly affect RUP content.
\end{abstract}

Keywords: Processing, roasted soybean grain, rumen undegradable protein

\# Corresponding author: Hassan.rafiee@ag.iut.ac.ir

\section{Introduction}

Soybean seeds contain $19.2 \%$ oil and $39.2 \%$ protein (NRC, 2001). Soybean is therefore regarded as an economical and convenient source of dietary fat and protein (Dhiman et al., 1997). However, raw soybean contains several anti-nutritional factors that reduce its nutritional value, among which are antitrypsin, urease and hemagglutinins. To eliminate these anti-nutritional substances, soybean seeds are processed. Heat is the most common way of doing so (Reddy et al., 1993). Heating results in cross linking between the peptide chain (free amino acid groups) and carbohydrate (sugar aldehyde groups), thus decreasing protein solubility and increasing the rumen bypass protein (Reddy et al., 1993; Dhiman et al., 1997). The processing temperature must be controlled carefully to ensure that the beans are heated sufficiently to eliminate anti-nutritional factors, but not excessively as this could increase processing costs and reduce protein quality. High temperatures also damage the nutritional value of soybean seeds, because they reduce the degradability of protein in the rumen and small intestine (Reddy et al., 1993).

Extrusion (Annextad et al., 1987), forced-air oven treatment (Faldet el al., 1992b) and roasting (Faldet \& Satter, 1991) are among the thermal methods that are used to process soybean seeds. Energy and fixed costs are lower for roasting than for extrusion (Reddy et al., 1993). Socha (1991) reviewed 16 published feeding trials and reported that, compared with soybean meal and raw soybeans, roasted soybeans increased milk production in dairy cows by $1.65 \mathrm{~kg} /$ day and fat-corrected milk (FCM) by $1.95 \mathrm{~kg} / \mathrm{day}$. There was no effect, however, on dry matter (DM) intake. Roasted soybeans could be considered an excellent source of RUP, but there could be variations in quality. For example, Faldet et al. (1991) examined 13 samples of roasted soybeans and found that product quality varied greatly. Rumen undegradable protein 
content ranged from $48 \%$ to $61 \%$ of crude protein (CP). There is little information about the holding times and particle sizes of roasted soybean. Faldet et al. (1992b) reported that the optimal heat treatment for soybeans in a forced air oven was $140{ }^{\circ} \mathrm{C}$ for 120 minutes. Dhiman et al. (1997) concluded that roasted soybeans in half and quarter sizes are optimal for milk production. The nutritional qualities of soybean proteins are essentially determined by amino acid composition, amino acid availabilities (digestibility) and the contents of biologically active components. Of these factors, the last two are mostly affected by processing conditions (Del Valle, 1981). In general, different conditions of processing could have significant impacts on the amount of bypass protein available in roasted soybeans (Faldet et al., 1991; 1992a).

In vivo, in vitro and in sacco techniques are employed to estimate the ruminal degradability of protein in feedstuffs (Elwakeel et al., 2007). The best method for evaluating protein source is the in sacco approach, but it is expensive, needs cannulated animals and is not practical for the usual evaluation of feeds. On the other hand, it is good for estimating ruminal protein degradation, but soluble and small particles of protein could leave the bags through the pores without complete degradation (Ho et al., 2008). Simple procedures that are suitable for use by commercial feed testing laboratories are required to monitor the quality of an increasing supply of heat-processed soybeans that are intended as a protein and energy supplement for ruminants. The protein dispersibility index (PDI) has been claimed to have the most constant response to heating full-fat soybeans. Another in vitro procedure that is used to estimate protein quality is the Cornell Net Carbohydrate and Protein System (CNCPS) (Sniffen et al., 1992).

The CNCPS is one of the schemes that have been developed to fractionate protein in feeds. In this system, feed protein is partitioned into three fractions: non protein nitrogen (fraction A), true protein (fraction $B$ ) and undegradable true protein (fraction $C$ ). True protein, based on its rates of rumen degradation, is divided into three subfractions $\left(B_{1}, B_{2}\right.$ and $\left.B_{3}\right)$. The rumen degradation rates of $B_{1}, B_{2}$ and $B_{3}$ fractions are $120 \%$ to $400 \% / \mathrm{h}, 3 \%$ to $16 \% / \mathrm{h}$, and $0.06 \%$ to $0.55 \% / \mathrm{h}$, respectively (Schwab et al., 2003). Fractions A and $\mathrm{B}_{1}$ are soluble and rapidly degraded in the rumen (soluble protein). The fractions of protein in CNCPS system are A (NPN, soluble in borate-phosphate buffer, but not precipitated with trichloroacetic acid); $B_{1}$ (rapidly degradable true protein; soluble in borate-phosphate buffer and precipitated with trichloroacetic acid); $B_{2}$ (moderately degradable true protein, calculated as the difference between total $C P$ and the sum of the other four $\mathrm{CP}$ fractions); $\mathrm{B}_{3}$ (slowly degradable true protein, calculated as the difference between neutral detergent insoluble $\mathrm{CP}$ [NDICP] and acid detergent insoluble $\mathrm{CP}$ [ADICP]); and $\mathrm{C}$ (undegradable true protein, measured as ADICP) (Licitra et al., 1996; Schwab et al., 2003).

The use of roasted soybeans in the diet of dairy cows is common. However, factors such as temperature, heating time and particle size could influence the quality. The most suitable conditions for roasting are unknown and need further research. The main objective of this study was to use the CNCPS system and PDI method to estimate the effects of temperature, roasting time and particle size of soybean on protein fractions and bypass protein.

\section{Materials and Methods}

First, soybean seeds were prepared from the same batch in three particle sizes (whole, coarsely ground and finely ground). The coarse-grounds and fine-ground soybeans were obtained by passing whole soybean through a hammer mill (model 55, Gehl Bros Mfg Co, West Bend, Wis) using $9 \mathrm{~mm}$ and $6 \mathrm{~mm}$ screen sizes, respectively. The geometric mean particle size was then calculated with a dry-sieving technique (ASAE, 1995). For this evaluation, $100 \mathrm{~g}$ of each experimental soybean was sieved in duplicate in a column with a series of eight sieves, with $6.35,4.75,3.35,2.36,2.00,1.70,0.85$ and 0.60 apertures, in a vertical oscillator for 10 minutes. The mean particle size (MPS) was calculated by fitting the data to a log normal distribution (Ensor el al., 1970). The average geometric mean particle sizes were $5.30 \mathrm{~mm}, 1.15 \mathrm{~mm}$ and $1.05 \mathrm{~mm}$ for whole, coarsely ground and finely ground soybean, respectively. The distribution of soybean particles on the sieves is shown in Table 1.

Soybeans in various particle sizes were roasted at 115,130 and $145^{\circ} \mathrm{C}$ (Gem Roaster, Winona, Minn) and held at that temperature for 5, 10 and 15 minutes. The soybeans were allowed to cool immediately after being removed from the roaster. Subsequently, in this trial the researchers had 27 treatments, three particle sizes (whole, coarse and fine), three roasting temperature $\left(115^{\circ} \mathrm{C}, 130^{\circ} \mathrm{C}\right.$ and $145^{\circ} \mathrm{C}$ ) and three holding times (5, 10 and $15 \mathrm{~min}$ ). Dry matter content of soybean samples was determined after drying at $60^{\circ} \mathrm{C}$ in a forced-air oven for 48 hours, and ground to pass through a 1-mm screen (Wiley mill, Arthur $\mathrm{H}$. Thomas Co, Philadelphia, Phil). The ground samples were analysed for neutral detergent fibre (NDF) through heat stable alpha-amylase (100 $\mu \mathrm{L} / \mathrm{sample}$ ) (Van Soest et al., 1991), ash, CP (AOAC, 2000) and acid detergent fibre (ADF) (Van Soest et al., 1991). Extra samples of the NDF and ADF components were processed for their acid detergent insoluble CP (ADICP) and neutral detergent insoluble $\mathrm{CP}$ (NDICP). Nitrogenous fractions of diets were partitioned into five fractions, $A, B_{1}, B_{2}, B_{3}$ and $C$, 
according to CNCPS (Sniffen et al., 1992), using standardization of procedures for nitrogen fractionation, as described by Licitra et al. (1996) (three replicates).

The RDP and RUP values were computed using the following equations:

$R D P=A+B_{1}\left[k_{d} B_{1} /\left(k_{d} B_{1}+k_{p}\right)\right]+B_{2}\left[k_{d} B_{2} /\left(k_{d} B_{2}+k_{p}\right)\right]+B_{3}\left[k_{d} B_{3} /\left(k_{d} B_{3}+k_{p}\right)\right]$

$\mathrm{RUP}=\mathrm{B}_{1}\left[\mathrm{k}_{\mathrm{p}} /\left(\mathrm{k}_{\mathrm{d}} \mathrm{B}_{1}+\mathrm{k}_{\mathrm{p}}\right)\right]+\mathrm{B}_{2}\left[\mathrm{k}_{\mathrm{p}} /\left(\mathrm{k}_{\mathrm{d}} \mathrm{B}_{2}+\mathrm{k}_{\mathrm{p}}\right)\right]+\mathrm{B}_{3}\left[\mathrm{k}_{\mathrm{p}} /\left(\mathrm{k}_{\mathrm{d}} \mathrm{B}_{3}+\mathrm{k}_{\mathrm{p}}\right)\right]+\mathrm{C}$

The rate of passage $\left(k_{p}\right)$ was equal to $0.08 \% / h$ and the rates of degradation $\left(k_{d}\right)$ for parts $B_{1}, B_{2}$ and $\mathrm{B}_{3}$ were taken to be $150 \%, 5 \%$ and $0.18 \%$ per hour, respectively.

Table 1 Least squares means of distribution of soybean particles on the sieves

\begin{tabular}{|c|c|c|c|c|c|c|c|c|c|c|}
\hline \multirow{2}{*}{ Item } & \multicolumn{3}{|c|}{ Roasting temperature, ${ }^{\circ} \mathrm{C}$} & \multicolumn{3}{|c|}{ Holding time, min } & \multicolumn{3}{|c|}{ Particle size, $\mathrm{mm}$} & \multirow{2}{*}{$\begin{array}{l}\text { Raw } \\
\text { seed }\end{array}$} \\
\hline & 115 & 130 & 145 & 5 & 10 & 15 & ws & cs & FS & \\
\hline \multicolumn{11}{|c|}{ Mean geometric particle size, $\mathrm{mm}$} \\
\hline & $2.52^{\mathrm{a}}$ & $2.51^{\mathrm{a}}$ & $2.47^{\mathrm{b}}$ & $2.50^{\mathrm{a}}$ & $2.53^{\mathrm{ab}}$ & $2.47^{\mathrm{b}}$ & $5.30^{\mathrm{a}}$ & $1.15^{\mathrm{b}}$ & $1.05^{\mathrm{c}}$ & 5.69 \\
\hline \multicolumn{11}{|c|}{ Sieve opening, mm } \\
\hline 6.35 & $17.10^{\mathrm{a}}$ & $17.55^{\mathrm{a}}$ & $15.88^{\mathrm{b}}$ & 17.05 & 17.25 & 16.23 & $49.51^{\mathrm{a}}$ & $0.25^{\mathrm{b}}$ & $0.76^{\mathrm{b}}$ & 67.36 \\
\hline 4.75 & $16.57^{\mathrm{a}}$ & $15.53^{\mathrm{ab}}$ & $15.72^{b}$ & 15.66 & 16.46 & 15.70 & $43.90^{\mathrm{a}}$ & $2.95^{\mathrm{b}}$ & $0.97^{\mathrm{C}}$ & 29.81 \\
\hline 3.35 & 4.76 & 4.81 & 4.66 & $4.78^{\mathrm{ab}}$ & $5.01^{\mathrm{a}}$ & $4.44^{\mathrm{b}}$ & $4.68^{\mathrm{b}}$ & $8.14^{\mathrm{a}}$ & $1.40^{\mathrm{C}}$ & 2.17 \\
\hline 2.36 & $12.83^{\mathrm{a}}$ & $13.12^{\mathrm{a}}$ & $10.76^{b}$ & 12.23 & 12.29 & 12.18 & $1.36^{\mathrm{c}}$ & $22.56^{\mathrm{a}}$ & $12.80^{b}$ & 0.46 \\
\hline 2.00 & 6.50 & 6.79 & 6.22 & 6.71 & 6.19 & 6.61 & $0.10^{c}$ & $8.49^{b}$ & $10.92^{\mathrm{a}}$ & 0.09 \\
\hline 1.70 & $11.02^{\mathrm{a}}$ & $10.02^{\mathrm{ab}}$ & $9.78^{\mathrm{b}}$ & 9.88 & 10.90 & 10.03 & $0.10^{c}$ & $13.03^{b}$ & $17.67^{\mathrm{a}}$ & 0.08 \\
\hline 0.85 & $25.89^{b}$ & $25.73^{b}$ & $30.35^{\mathrm{a}}$ & $27.35^{\mathrm{b}}$ & $25.38^{c}$ & $29.24^{\mathrm{a}}$ & $0.18^{\mathrm{c}}$ & $34.03^{b}$ & $47.76^{\mathrm{a}}$ & 0.00 \\
\hline 0.60 & 2.90 & 2.58 & 2.91 & $3.17^{\mathrm{a}}$ & $2.77^{\mathrm{ab}}$ & $2.45^{\mathrm{b}}$ & $0.04^{c}$ & $4.72^{\mathrm{a}}$ & $3.63^{b}$ & 0.00 \\
\hline pan & $3.22^{\mathrm{ab}}$ & $3.79^{\mathrm{a}}$ & $2.80^{\mathrm{b}}$ & $3.12^{\mathrm{ab}}$ & $3.72^{\mathrm{a}}$ & $2.98^{\mathrm{b}}$ & $0.02^{\mathrm{c}}$ & $5.73^{\mathrm{a}}$ & $4.06^{\mathrm{b}}$ & 0.03 \\
\hline
\end{tabular}

${ }^{\mathrm{a}, \mathrm{b}, \mathrm{c}}$ Row means with different superscripts differ significantly at $P<0.05$.

WS: whole soybean; CS: coarse-ground soybean; FS: fine-ground soybean.

The PDI procedure involved blending $20 \mathrm{~g}$ of the ground soybean sample with $300 \mathrm{~mL}$ distilled water for $10 \mathrm{~min}$ in a Waring blender, which operated at $8500 \mathrm{rpm}$ and $21^{\circ} \mathrm{C}$. After blending, the mixture was centrifuged at $1118 \times \mathrm{g}(2500 \mathrm{rpm})$ (Beckman 12-21 centrifuge with JA-14 rotor; Beckman Instruments, Inc., Palo Alto, Calif) for 10 min. The supernatant was analysed for Kjeldahl-N to obtain a PDI such that PDI = (total supernatant CP/total CP in blended soybean sample) $x 100$ (AOCS, 1985). Hsu \& Satter (1995) concluded that the ideal range for PDI was $9 \%$ to $11 \%$. A PDI between $11 \%$ and $14 \%$ indicated marginal heating, and underheated soybeans have a PDI greater than 14\% (Satter et al., 1993). PDI values above $14 \%$ corresponded with being under-processed, whereas values below $9 \%$ were related to over-processing (Hsu \& Satter, 1995). The data were subjected to ANOVA with the general linear models (GLM) procedure proposed by the SAS Institute, Inc. (SAS, 2001). Results were analysed according to a $3 \times 3 \times 3$ factorial design (27 treatments with three replicates), with raw soybeans being studied as controls. The main sources of variation were particle size, roasting temperature and holding time. Sums of squares for treatments were partitioned to provide linear (L) and quadratic (Q) contrasts. Significant differences between individual means were identified using the Duncan test. Significance was set at $P<0.05$, and a trend toward significance was taken at $P<0.10$ unless stated otherwise. The basic model was:

$$
\mathrm{Y}_{\mathrm{ijk}}=\mu+\mathrm{P}_{\mathrm{i}}+\mathrm{T}_{\mathrm{j}}+\mathrm{H}_{\mathrm{k}}+\mathrm{e}_{\mathrm{ijk}}
$$

where $Y_{i j k}=$ all dependent variables represented; $\mu$ = overall mean; $P_{i}=$ the average effect of particle size $i$; $T_{j}=$ the average effect of roasting temperature $j ; H_{k}=$ the average effect of holding time temperature $k ; e_{i j k}$ $=$ random residual assumed to be normally distributed.

The Pearson correlation coefficients were estimated using the CORR procedure of SAS (2001). 


\section{Results}

The distribution of soybean particles on the sieves is shown in Table 1. The particle size decreased with increased roasting temperatures and holding times, because soybeans roasted at $145^{\circ} \mathrm{C}$ or held for 15 min in the roaster had lower MPS compared with other roasting temperatures and holding times.

The effects of processing on DM, organic matter (OM), CP, NDF, NDICP, ADF and ADICP are shown in Table 2. Dry matter was increased linearly with increasing time and temperature $(P<0.01)$, and coarseground soybean had the highest DM (96.8\%). Roasting temperature had no effect on OM $(P>0.05)$, whereas with increasing the roasting time and particle size of soybeans, OM level was raised linearly $(P$ $<0.01)$. Crude protein percentage was not influenced by treatments. ADF level was not significantly changed by the roasting time either. A quadratic response occurred with roasting temperature for ADF; the roasting temperature of 130 had the lowest ADF concentration (14.28\%). However, the NDF level increased linearly with the time and temperature of roasting $(P<0.05)$. There was a linear increase in ADF and NDF levels as the particle size of the roasted soybean was decreased $(P<0.01)$. The ADICP and NDICP levels of roasted soybeans followed the same trend as ADF and NDF levels. In general, DM, OM and NDICP were increased and NDF and ADICP were decreased in the roasted soybean, in comparison with the raw soybean.

Table 2 Least squares means of processing effect on different parts of roasted soybeans (\% dry matter)

\begin{tabular}{|c|c|c|c|c|c|c|c|c|c|c|}
\hline \multirow{2}{*}{ Item } & \multicolumn{3}{|c|}{ Roasting temperature, ${ }^{\circ} \mathrm{C}$} & \multicolumn{3}{|c|}{ Holding time, min } & \multicolumn{3}{|c|}{ Particle size, $\mathrm{mm}$} & \multirow{2}{*}{$\begin{array}{l}\text { Raw } \\
\text { seed }\end{array}$} \\
\hline & 115 & 130 & 145 & 5 & 10 & 15 & WS & CS & FS & \\
\hline DM & $94.7^{\mathrm{C}}$ & $96.4^{b}$ & $97.8^{\mathrm{a}}$ & $95.6^{c}$ & $96.3^{\mathrm{b}}$ & $97.1^{\mathrm{a}}$ & $96.5^{b}$ & $96.8^{\mathrm{a}}$ & $95.5^{c}$ & 88.5 \\
\hline OM & 93.6 & 93.8 & 93.8 & $93.5^{b}$ & $93.8^{\mathrm{a}}$ & $93.9^{\mathrm{a}}$ & $94.2^{\mathrm{a}}$ & $93.7^{b}$ & $93.6^{c}$ & 92.5 \\
\hline $\mathrm{CP}$ & 39.82 & 39.91 & 40.08 & 39.84 & 39.74 & 40.23 & 39.69 & 39.77 & 40.35 & 38.62 \\
\hline ADF & $15.57^{\mathrm{a}}$ & $14.28^{\mathrm{b}}$ & $15.00^{\mathrm{a}}$ & 15.00 & 15.03 & 14.82 & $16.98^{\mathrm{a}}$ & $14.82^{b}$ & $13.04^{c}$ & 16.94 \\
\hline ADICP & $3.87^{\mathrm{ab}}$ & $3.80^{\mathrm{b}}$ & $4.31^{\mathrm{a}}$ & 4.01 & 4.04 & 3.93 & $4.96^{a}$ & $3.83^{b}$ & $3.19^{c}$ & 5.08 \\
\hline NDF & $21.95^{\mathrm{b}}$ & $22.14^{b}$ & $26.24^{\mathrm{a}}$ & $22.68^{b}$ & $23.21^{\mathrm{ab}}$ & $24.44^{\mathrm{a}}$ & $25.96^{\mathrm{a}}$ & $23.49^{b}$ & $20.88^{c}$ & 21.27 \\
\hline NDICP & $8.90^{c}$ & $10.03^{b}$ & $15.03^{\mathrm{a}}$ & $10.46^{b}$ & $11.13^{b}$ & $12.37^{\mathrm{a}}$ & $12.91^{\mathrm{a}}$ & $11.65^{b}$ & $9.40^{\mathrm{C}}$ & 6.26 \\
\hline
\end{tabular}

${ }^{a, b, c}$ Row means with different superscripts differ significantly at $P<0.05$.

WS: whole soybean; CS: coarse-ground soybean; FS: fine-ground soybean.

DM: dry matter; OM: organic matter; CP: crude protein; ADF: acid detergent fibre; NDF: neutral detergent fibre assayed with a heat stable amylase and expressed inclusive of residual ash; NDICP: neutral detergent insoluble CP;

ADICP: acid detergent insoluble CP.

The effects of processing on different fractions of protein are presented in Table 3. The non-protein nitrogen (NPN, A fraction) declined linearly with increasing roasting time and temperature and particle size of soybean $(P<0.05)$. True protein (including $\mathrm{B}_{1}, \mathrm{~B}_{2}$ and $\mathrm{B}_{3}$ fractions) was increased linearly with increasing the time and temperature of roasting $(P<0.01)$. Also, a quadratic effect of particle size of soybean in true protein was observed $(P=0.07)$. The effect of roasting temperature on different fractions of protein $(\% \mathrm{CP})$ is presented in Figure 1.

True protein was higher for coarse-ground soybeans, compared with whole and finely ground $(32.8 \%$ vs. $31.7 \%$ and $31.8 \%$ DM, respectively). Rapidly degradable true protein ( $\mathrm{B}_{1}$ fraction) declined linearly with increasing the time and temperature of roasting and grinding the soybean $(P<0.05)$. Moderately degradable true protein $\left(\mathrm{B}_{2}\right.$ fraction) also showed a quadratic effect of roasting temperature $(P<0.01)$. Soybeans roasted at $130{ }^{\circ} \mathrm{C}$ had higher $\mathrm{B}_{2}$ compared with those roasted at 115 and $145{ }^{\circ} \mathrm{C}$ (an average of $23.5 \%$ vs. $22.5 \%$ and $19.6 \% \mathrm{DM}$, respectively). The effects of holding time on different fractions of protein (\%CP) are presented in Figure 2.

Fraction $\mathrm{B}_{2}$ was increased with the time of roasting and grinding level $(P<0.05)$. Slowly degradable true protein ( $\mathrm{B}_{3}$ fraction) increased with expanding particle size, time and temperature of roasting $(P<0.05)$. Generally, processing reduced NPN, and $B_{1}$ and $C$ fractions and increased $B_{2}$ and $B_{3}$ parts in the roasted soybeans, compared with the raw ones. 
Table 3 Least squares means of processing effect on protein fractions of roasted soybeans (\% dry matter)

\begin{tabular}{|c|c|c|c|c|c|c|c|c|c|c|}
\hline \multirow{2}{*}{ Item } & \multicolumn{3}{|c|}{ Roasting temperature ${ }^{\circ} \mathrm{C}$} & \multicolumn{3}{|c|}{$\begin{array}{l}\text { Holding time } \\
\text { min }\end{array}$} & \multicolumn{3}{|c|}{$\begin{array}{c}\text { Particle size } \\
\text { mm }\end{array}$} & \multirow{2}{*}{$\begin{array}{l}\text { Raw } \\
\text { seed }\end{array}$} \\
\hline & 115 & 130 & 145 & 5 & 10 & 15 & WS & CS & FS & \\
\hline$A$ & $4.77^{\mathrm{a}}$ & $3.68^{b}$ & $3.01^{b}$ & $4.72^{\mathrm{a}}$ & $3.79^{a b}$ & $2.95^{\mathrm{b}}$ & $3.01^{\mathrm{b}}$ & $3.13^{b}$ & $5.32^{\mathrm{a}}$ & 9.47 \\
\hline B & $31.17^{\mathrm{b}}$ & $32.42^{\mathrm{a}}$ & $32.75^{\mathrm{a}}$ & $31.10^{\mathrm{C}}$ & $31.91^{\mathrm{b}}$ & $33.33^{\mathrm{a}}$ & $31.70^{\mathrm{b}}$ & $32.80^{\mathrm{a}}$ & $31.83^{b}$ & 24.07 \\
\hline $\mathrm{B}_{1}$ & $3.63^{\mathrm{a}}$ & $3.05^{\mathrm{ab}}$ & $2.39^{b}$ & $3.99^{\mathrm{a}}$ & $2.86^{\mathrm{b}}$ & $2.21^{\mathrm{b}}$ & $4.61^{\mathrm{a}}$ & $2.49^{b}$ & $1.97^{\mathrm{b}}$ & 17.64 \\
\hline $\mathrm{B}_{2}$ & $22.50^{\mathrm{a}}$ & $23.15^{\mathrm{a}}$ & $19.63^{b}$ & $20.66^{b}$ & $21.95^{\mathrm{a}}$ & $22.68^{\mathrm{a}}$ & $19.15^{b}$ & $22.48^{\mathrm{a}}$ & $23.65^{a}$ & 5.25 \\
\hline $\mathrm{B}_{3}$ & $5.02^{c}$ & $6.22^{b}$ & $10.71^{a}$ & $6.44^{\mathrm{b}}$ & $7.09^{b}$ & $8.43^{a}$ & $7.94^{\mathrm{a}}$ & $7.82^{\mathrm{a}}$ & $6.20^{\mathrm{b}}$ & 1.17 \\
\hline C & $3.87^{a b}$ & $3.80^{\mathrm{b}}$ & $4.31^{\mathrm{a}}$ & 3.93 & 4.04 & 4.01 & $4.96^{\mathrm{a}}$ & $3.83^{b}$ & $3.19^{c}$ & 5.08 \\
\hline
\end{tabular}

${ }^{a, b, c}$ Row means with different superscripts differ significantly at $P<0.05$.

WS: whole soybean; CS: coarse-ground soybean; FS: fine-ground soybean.

A: non-protein nitrogen; $B$ : true protein; $C$ : un-degradable true protein; $B_{1}$ : rapidly degradable true protein;

$\mathrm{B}_{2}$ : moderately degradable true protein; $\mathrm{B}_{3}$ : slowly degradable true protein.

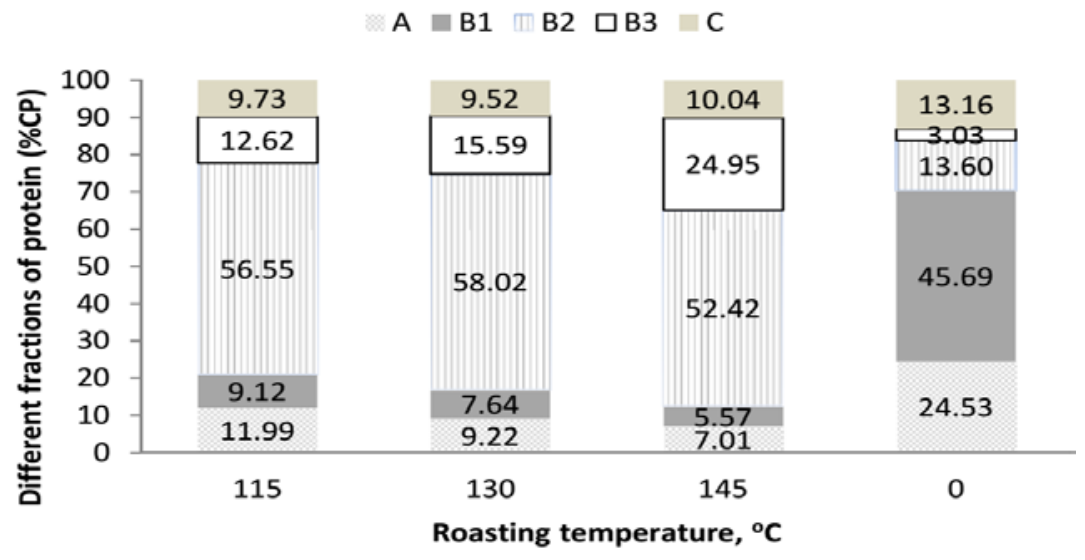

Figure 1 Effects of roasting temperature on different fractions of protein (\% crude protein (CP)).

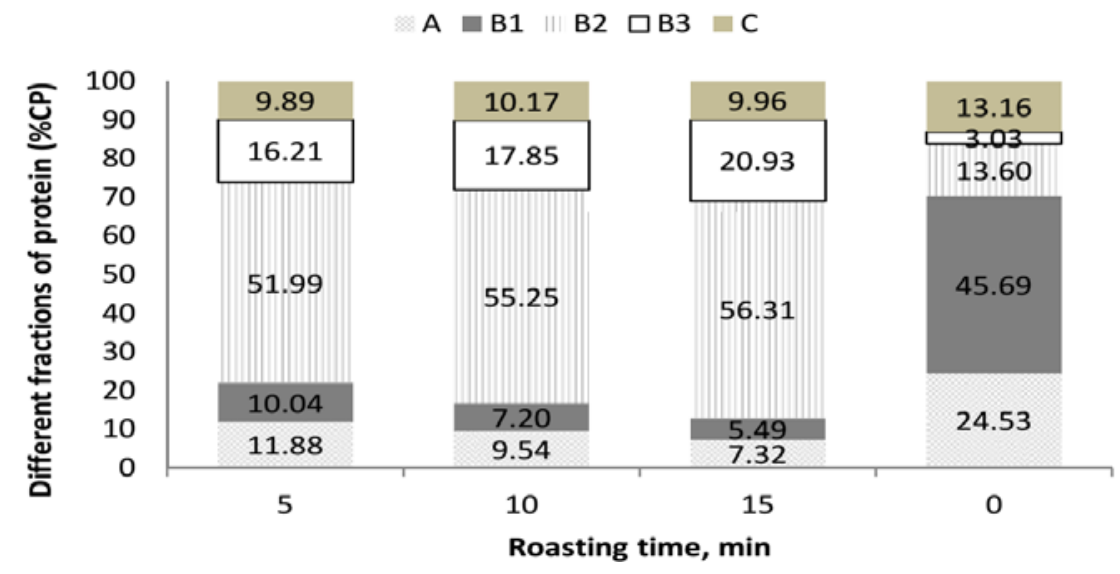

Figure 2 Effects of holding time on different fractions of protein (\% crude protein (CP)).

Treatment effects on soluble and bypass protein can be seen in Table 4. Soluble protein decreased linearly with increasing the time and temperature of roasting $(P<0.01)$. Particle size had a quadratic effect on soluble protein. Soybeans with $1.15 \mathrm{~mm}$ particle size had lower soluble protein than those of 5.30 and 
$1.05 \mathrm{~mm}$ (an average of $5.63 \%$ vs. $7.62 \%$ and $7.29 \% \mathrm{DM}$, respectively). Increasing the time and temperature of roasting linearly enhanced RUP and decreased RDP. There was no difference between whole and coarsely ground soybeans in RUP and RDP content, but the finely ground soybean had lower RUP than whole and coarsely ground soybeans $(P<0.05)$. PDI declined linearly with increasing the time and temperature of roasting and increased linearly with decreasing the particle size of soybean grains $(P<0.05)$. In general, the roasted soybeans had lower soluble protein and PDI and higher bypass protein than raw ones. The effects of particle size of soybean on different fractions of protein (\% CP) are presented in Figure 3. The correlation between RUP and the variable that affected the RUP content of the roasted soybean is presented in Table 5.

Table 4 Least squares means of processing effect on soluble protein, rumen degradable protein and rumen undegradable protein and protein dispersibility index of roasted soybeans (\% dry matter)

\begin{tabular}{|c|c|c|c|c|c|c|c|c|c|c|}
\hline \multirow{2}{*}{ Item } & \multicolumn{3}{|c|}{ Roasting temperature, ${ }^{\circ} \mathrm{C}$} & \multicolumn{3}{|c|}{ Holding time, min } & \multicolumn{3}{|c|}{ Particle size, mm } & \multirow{2}{*}{$\begin{array}{l}\text { Raw } \\
\text { seed }\end{array}$} \\
\hline & 115 & 130 & 145 & 5 & 10 & 15 & ws & cs & FS & \\
\hline SP & $8.41^{\mathrm{a}}$ & $6.73^{\mathrm{b}}$ & $5.41^{b}$ & $8.71^{\mathrm{a}}$ & $6.66^{\mathrm{b}}$ & $5.17^{\mathrm{c}}$ & $7.62^{\mathrm{a}}$ & $5.63^{\mathrm{b}}$ & $7.29^{\mathrm{a}}$ & 27.11 \\
\hline RUP & $23.24^{c}$ & $24.29^{b}$ & $27.00^{\mathrm{a}}$ & $23.24^{\mathrm{c}}$ & $24.62^{b}$ & $26.25^{\mathrm{a}}$ & $24.75^{\mathrm{b}}$ & $25.44^{\mathrm{a}}$ & $23.92^{c}$ & 9.28 \\
\hline RDP & $16.99^{\mathrm{a}}$ & $15.62^{b}$ & $13.07^{\mathrm{c}}$ & $16.60^{\mathrm{a}}$ & $15.11^{\mathrm{b}}$ & $13.97^{\mathrm{b}}$ & $14.93^{b}$ & $14.32^{\mathrm{b}}$ & $16.43^{\mathrm{a}}$ & 29.38 \\
\hline $\mathrm{PDI}(\%)$ & $13.28^{\mathrm{a}}$ & $7.10^{\mathrm{b}}$ & $6.78^{\mathrm{c}}$ & $10.81^{\mathrm{a}}$ & $9.49^{b}$ & $6.86^{\mathrm{c}}$ & $6.90^{\mathrm{c}}$ & $8.29^{b}$ & $11.97^{\mathrm{a}}$ & 54.89 \\
\hline
\end{tabular}

${ }^{a, b, c}$ Row means with different superscripts differ significantly at $P<0.05$.

WS: whole soybean; CS: coarse-ground soybean; FS: fine-ground soybean;

SP: soluble protein; RUP: rumen undegradable protein; RDP: rumen degradable protein;

PDI: protein dispersibility index.

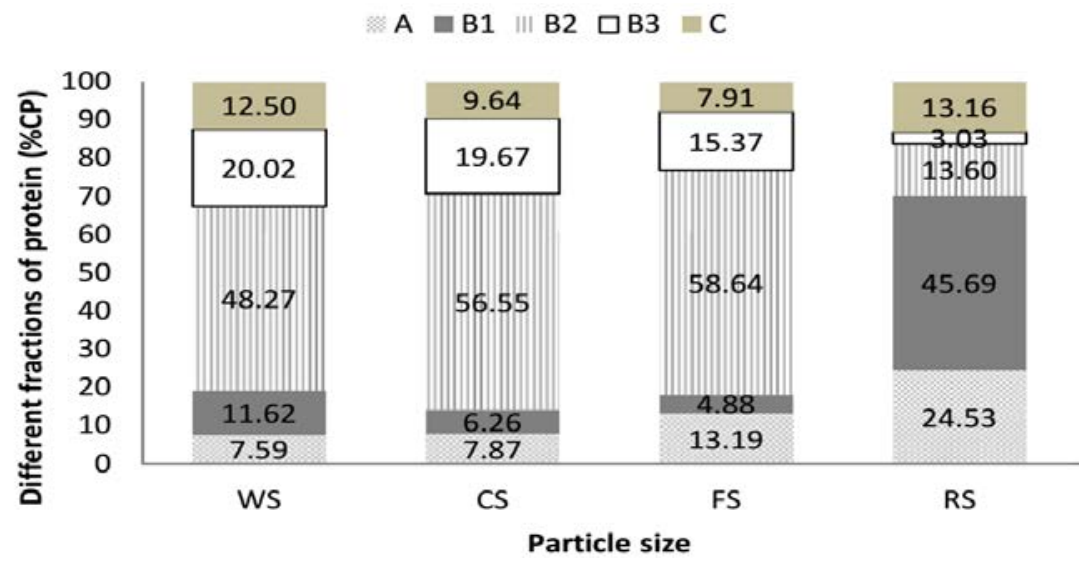

Figure 3 Effects of particle size of soybean on different fractions of protein, \% crude protein (CP) (WS: whole soybean; CS: coarse-ground soybean; FS: fine-ground soybean; RS: raw soybean).

\section{Discussion}

Thermal processing reduced the A fraction of protein (NPN) (Hsu \& Satter, 1995; Ljukjel et al., 2000; Kafilzadeh et al., 2013). The reduction in the NPN component from heating was presumably because of the loss of amino acids (Ljukjel et al., 2000). One of the first noticeable changes of proteins on heating (even at temperatures around $100^{\circ} \mathrm{C}$ ) was the loss of labile amino acids such as cysteine and lysine. Lysine is one of the most temperature-sensitive amino acids and destruction of lysine is often 5 to 15 times greater than that occurring with other amino acids (Dakowski et al., 1996).

Heat treatment of mustard meal reduced the $B_{1}$ fraction and increased the $B_{2}$ and $B_{3}$ fractions, compared with the raw mustard meal (Mustafa et al., 1999). The increase in the $B_{2}$ and $B_{3}$ fractions reduced RDP in heat treatment of mustard meal (Mustafa et al., 1999). Relative to the control, heated mustard meal had lower effective in vitro CP degradability ( $44.5 \%$ vs. $74.6 \%$ of $\mathrm{CP})$ and a higher ruminal escape CP 
(61.5\% vs. $12.0 \%$ of $C P$ ) value (Mustafa et al., 1999). Kafilzadeh et al. (2013) reported that thermal processing of canola seed increased $B_{2}$ and $B_{3}$, and decreased $A$ and $B_{1}$ fractions, compared with the untreated varieties.

Table 5 Significant $(P<0.05)$ simple correlations among rumen degradable proteins and variables that affect rumen undegradable protein content of roasted soybean $(n=54)^{1}$

\begin{tabular}{|c|c|c|c|c|c|c|c|c|c|c|c|c|c|}
\hline & RUP & HEAT & TIME & SIZE & A & $B_{1}$ & $\mathrm{~B}_{2}$ & $\mathrm{~B}_{3}$ & B & SP & C & NDICP & PDI \\
\hline RUP & 1 & 0.62 & 0.43 & NS & -0.70 & -0.48 & NS & 0.70 & 0.59 & -0.88 & 0.29 & 0.75 & -0.51 \\
\hline HEAT & & 1 & NS & NS & -0.31 & NS & -0.32 & 0.71 & 0.26 & -0.39 & NS & 0.70 & -0.47 \\
\hline TIME & & & 1 & NS & 0.39 & -0.44 & NS & $0.23^{\star}$ & 0.36 & -0.46 & NS & NS & -0.30 \\
\hline SIZE & & & & 1 & 0.39 & -0.44 & 0.43 & NS & NS & NS & -0.67 & -0.41 & 0.38 \\
\hline A & & & & & 1 & NS & NS & -0.36 & -0.87 & 0.63 & -0.38 & -0.46 & 0.45 \\
\hline $\mathrm{B}_{1}$ & & & & & & 1 & -0.55 & NS & NS & 0.69 & NS & NS & NS \\
\hline $\mathrm{B}_{2}$ & & & & & & & 1 & -0.58 & $0.23^{*}$ & -0.50 & $-.23^{*}$ & -0.61 & 0.21 \\
\hline $\mathrm{B}_{3}$ & & & & & & & & 1 & 0.36 & -0.35 & NS & 0.94 & -0.53 \\
\hline B & & & & & & & & & 1 & -0.60 & NS & 0.30 & -0.40 \\
\hline SP & & & & & & & & & & 1 & NS & -0.36 & 0.34 \\
\hline C & & & & & & & & & & & 1 & 0.37 & NS \\
\hline NDIN & & & & & & & & & & & & 1 & -0.54 \\
\hline PDI & & & & & & & & & & & & & 1 \\
\hline
\end{tabular}

${ }^{1}$ RUP and variables data are in percentage of protein. RUP: rumen undegradable protein; HEAT: roasting temperature, ${ }^{\circ} \mathrm{C}$; TIME: holding time, min; SIZE: particle size, $\mathrm{mm}$; $\mathrm{A}$ : protein fraction $\mathrm{A} ; \mathrm{B}_{1}$ : protein fraction $\mathrm{B}_{1}$; $\mathrm{B}_{2}$ : protein fraction $\mathrm{B}_{2}$; $\mathrm{B}_{3}$ : protein fraction $\mathrm{B}_{3}$; $\mathrm{B}$ : protein fraction $\mathrm{B}$; SP: soluble protein; $\mathrm{C}$ : protein fraction $\mathrm{C}$; NDICP: neutral detergent insoluble $\mathrm{CP}$; PDI: protein dispersibility index.

NS: non significant $(P>0.10)$. * Trends toward significance $(0.05<P<0.10)$.

The increase in the slowly degradable fractions $\left(B_{3}\right.$ and $\left.B_{2}\right)$ as a result of heating could be attributed to the denaturation of the proteins as this has been shown to reduce their solubility (Van Soest, 1994). The increase in $B_{2}$ fraction on treating may account for loss in the $B_{1}$ fraction. Hence, it could be expected that the overall degradation rate would be decreased because of treating as a result of the shift from the rapidly ruminally degradable $B_{1}$ fraction to the slowly ruminally degradable $B_{2}$ fraction (Kafilzadeh et al., 2013).

The decreased CP solubility of protein supplements as a result of heat treatment is well documented (Ganesh \& Grieve, 1990; Moshtaghi Nia \& Ingalls, 1992; McAllister et al., 1993; Mustafa et al., 1999; Fathi Nasri et al., 2008). Heat treatment, which decreases rumen protein degradability, can result in a decrease in the percentage of $\alpha$-helixes and an increase in the percentage of $\beta$-sheets $(Y u, 2005)$. The major proportion of protein in soybeans is in the form of globulins, which are followed by albumins, with lesser amounts of glutelins and prolamins. Soybean globulin is apparently extractable by water (Van Soest, 1994). In addition, globulins and albumins are more sensitive to heat denaturation. Thus, rendering them water insoluble could reduce the soluble protein content (Ganesh \& Grieve, 1990). Pichard \& Van Soest (1977) stated that NDICP roughly represented the slowly degradable and undegradable fractions in plant cell walls.

In general, heat treatment increased NDICP (Mustafa et al., 1999, 2000, 2003; Kafilzadeh et al., 2013), but its effect on the acid detergent insoluble protein is different. In some articles, as a result of heat treatment, an increase in the amount of acid detergent insoluble protein (McKinnon et al., 1995) or no change (Mustafa et al., 1999; 2000; 2003; Kafilzadeh et al., 2013) was observed, and even a decrease (Ganesh \& Grieve, 1990; Faldet et al., 1991; Moshtaghi Nia \& Ingalls, 1992; Demjanec et al., 1995; Hsu \& Satter, 1995). The differences in the ADF and NDF content with increasing heat could be attributed to proteins that are less soluble, and some heat denatured proteins recovered in the NDF fraction (Moshtaghi Nia \& Ingalls, 1992). Therefore, the N content of NDF was greatly increased by heating, while ADF required the Maillard reaction or condensation of protein with carbohydrate to render protein recoverable in the ADF fraction (Van Soest, 1994). Heat facilitates the Maillard reaction, or non-enzymatic browning between sugar aldehyde groups and free amino acid groups of protein, yielding an amino-sugar complex. This complex is 
more resistant than normal peptides to enzymatic hydrolysis, and reversibility of this reaction is dependent on the temperature and duration of heat exposure (Lin \& Kung, 1999). However, no effect on acid detergent-insoluble protein was observed as a result of heating. These results indicated that possibly heat inputs used in the present study were not severe enough to generate unavailable protein via the Maillard reaction. Other researchers reported similar findings when applying modest heat treatments to soybean (Demjanec et al., 1995) and canola meal (Moshtaghi Nia \& Ingalls, 1992).

Soya hulls constitute approximately $9 \%$ of the total OM of the soybean seed, and contain about $68 \%$ NDF, 50\% ADF and 2\% lignin. Therefore, soya hulls could be regarded as the major contributor of NDF in soybeans. Soya hull loss occurred during grinding, leading to the lower NDF in ground beans (Ganesh \& Grieve, 1990). Heating temperature had more effect on slowly degraded protein $\left(B_{3}+B_{2}\right.$ fractions) than heating time and grinding. As a result, heating temperature had a greater effect on the RUP of roasted soybeans (Table 4). Petit et al. (1999; 2002) reported similar findings.

The PDI for the temperatures of 115,130 and $145^{\circ} \mathrm{C}$ was $13.28,7.10$ and 6.78 , respectively (Table 4). Only PDI at the temperature of $115^{\circ} \mathrm{C}$ is in the appropriate range (9 to 14). Soybean roasted at temperatures of 130 and $145^{\circ} \mathrm{C}$ has inadequate PDI (less than 9). The 5- and 10-minute roasting times had PDI in an appropriate range, but 10-minute roasting had more bypass protein than 5 minutes $(62.1 \%$ vs. $58.3 \% \mathrm{CP}$ ). Among particle sizes, finely ground particles had acceptable PDI (11.97). However, because the PDI of coarsely ground particles was close to 9 and was shown to have more bypass protein (64.0\% vs. $59.4 \% \mathrm{CP}$ ), the particle size of $1.15 \mathrm{~mm}$ could be recommended for roasted soybean.

The PDI assay is based on the solubility of soybean protein. Because soluble protein is decreased with increasing time and temperature, the PDI decreased linearly with increasing time and temperature of roasting. In agreement with the results of the current study, PDI decreased linearly with increased extrusion (Zhu et al., 1996; Anuonye et al., 2007; Palic et al., 2011) and roasting (Hsu \& Satter, 1995) temperatures. PDI decreased incrementally when heating soybean meal from 0 to 30 minutes (Batal et al., 2000; Caprita et al., 2010a; b). The results of the current experiment showed coarse soybean roasted at $115{ }^{\circ} \mathrm{C}$ for 10 minutes had optimum PDI and high RUP content.

In general, an optimum heat treatment could minimize soluble CP and maximize NDICP without a substantial increase in ADICP (Moshtaghi Nia \& Ingalls, 1992; McKinnon et al., 1995; Mustafa et al., 2003).

Correlation matrices for RUP and its variables were shown in Table 5. RUP was correlated (Pearson correlation) positively $(P<0.01)$ with the roasting temperature, holding time and $\mathrm{B}_{3}, \mathrm{~B}$ and NDICP fraction. The correlation between RUP and $C$ fraction of protein was relatively weaker $(P=0.02)$. The correlations between $A$ and $B_{1}$ fractions and SP and PDI with RUP were significant and negative. The particle size of roasted soybeans had no significant correlation with RUP. In terms of roasting temperature and holding time, temperature had a higher correlation with the RUP content of the roasted soybean.

\section{Conclusions}

The results of this experiment showed that different processing conditions (such as particle size, heating temperature and heating time) had significant impacts on different fractions of the protein, implying that the processing condition should be considered in preparing roasted soybeans. Heating temperature had more effect than holding time and particle size on protein fractions. The RUP level was increased linearly with raising the heating temperature, as the highest level was obtained at $145^{\circ} \mathrm{C}$. The rise in RUP at $145^{\circ} \mathrm{C}$ was accompanied by an increase in the slowly degradable true protein $\left(\mathrm{B}_{3}\right.$ fraction) and undegradable true protein (C fraction), while at $130^{\circ} \mathrm{C}$ and $115^{\circ} \mathrm{C}$, the moderately degradable true protein $\left(\mathrm{B}_{2}\right.$ fraction) was increased. The $B_{2}$ fraction could therefore be a better indicator of the probable bypass protein value of soybean than the $B_{3}$ fraction. Using the results of CNCPS and PDI methods showed that the soybean with the coarsely ground particles, which were roasted at $115^{\circ} \mathrm{C}$ for 10 minutes, could be recommended.

\section{Acknowledgments}

The authors thank Khaled Sadeghi (Bisotun Co., Isfahan, Iran) and his colleagues for their financial and technical support. The authors also thank H. Khoshouei and H. Ziaee (Nutrition Laboratory at the Department of Animal Science), and R. Pahlavan for assistance in laboratory and statistical analysis.

\section{Authors' contributions}

HRY was in charge of project design and writing of the manuscript. MA, GRG and ASS were in charge of project implementation. All co-authors participated in results, statistics and interpretation of the study.

\section{Conflict of interest declaration}

We certify that there is no conflict of interest with any financial organization regarding the material discussed in the manuscript. 


\section{References}

Annextad, R.J., Stern, M.D., Otterby, D.E., Linn, J.G. \& Hansen, W.P., 1987. Extruded soybeans and corn gluten meal as supplemental protein sources for lactating dairy cattle. J. Dairy Sci. 70, 814-822.

Anuonye, J.C., Badifu, G.I.O. \& Inyang, C.U., 2007. Protein digestibility index and trypsin inhibitor activity of extruded blends of acha/soybean: A response surface analysis. Am. J. Food Technol. 2, 502-511.

AOAC, 2000. Official Methods of Analysis, 17th ed. Association of Official Analytical Chemists, Arlington, USA.

AOCS, 1985. Official Methods and Recommended Practices of the American Oil Chemists Society. 3rd ed. Am. Oil Chern. Soc., Champaign, IL., USA.

ASAE, 1995. American National Standards Institute. Method of determining and expressing fineness of feed material by sieving. ASAE Standards, p. 461, ASAE, St. Joseph, MI. VA. USA.

Batal, A.B., Douglas, M.W., Engram, A.E. \& Parsons, C.M., 2000. Protein dispersibility index as an indicator of adequately processed soybean meal. Poult. Sci. 79, 1592-1596.

Caprita, R., Caprita, A., Gheorghe, I., Cretescu, I. \& Simulesku, V.O., 2010a. Laboratory procedures for assessing quality of soybean meal. Proc. World Congress on Engineering and Computer Science, WCECS 2010, vol. II, San Francisco, USA.

Caprita, R., Caprita, A. \& Cretescu, I., 2010b. Protein solubility as quality index for processed soybean. Anim. Sci. Biotechnol. 43, 375-378.

Dakowski, P., Weisbjerg, M.R. \& Hvelplund, T., 1996. The effect of temperature during processing of rape seed meal on amino acid degradation in the rumen and digestion in the intestine. Anim. Feed Sci. Technol. 58, 213-226.

Del Valle, F.R., 1981. Nutritional qualities of soya protein as affected by processing. JAOCS. 58, 419-429.

Demjanec, B., Merchen, N.R., Cremin, J.D., Aldrich, C.G. \& Berger, L.L., 1995. Effect of roasting on site and extent of digestion of soybean meal by sheep: I. Digestion of nitrogen and amino acids. J. Anim. Sci. 73, 824-834.

Dhiman, T.R., Korevaar, A.C. \& Satter, L.D., 1997. Particle size of roasted soybeans and the effect on milk production of dairy cows. J. Dairy Sci. 80, 1722-1727.

Elwakeel, E.A., Titgemeyer, E.C., Drouillard, J.S. \& Armendariz, C.K., 2007. Evaluation of ruminal nitrogen availability in liquid feeds. Anim. Feed Sci. Technol. 137, 163-181.

Ensor, W.L., Olson, H.H. \& Colenbrander, V.F., 1970. A report: Committee on classification of particle size in feedstuffs. J. Dairy Sci. 53, 689-690.

Faldet, M.A. \& Satter, L.D., 1991. Feeding heat treated full fat soybeans to cows in early lactation. J. Dairy Sci. 74, 3047-3054.

Faldet, M.A., Voss, V.L., Broderick, G.A. \& Satter, L.D., 1991. Chemical, in vitro and in situ evaluation of heat-treated soybean proteins. J. Dairy Sci. 74, 2548-2554.

Faldet, M.A., Son, Y.S. \& Satter, L.D., 1992a. Chemical, in vitro and in vivo evaluation of soybeans heat-treated by various processing methods. J. Dairy Sci. 75, 789-795.

Faldet, M.A., Satter, L.D. \& Broderick, G.A., 1992b. Determining optimal heat treatment of soybeans by measuring available lysine chemically and biologically with rats to maximize protein utilization by ruminants. J. Nutr. 122, 151-160.

Fathi Nasri, M.H., France, J., Danesh Mesgaran, M. \& Kebreab, E., 2008. Effect of heat processing on ruminal degradability and intestinal disappearance of nitrogen and amino acids in Iranian whole soybean. Livest. Sci. 113, 43-51.

Ganesh, D. \& Grieve, D.G., 1990. Effect of roasting raw soybeans at three temperatures on in situ dry matter and nitrogen disappearance in dairy cows. J. Dairy Sci. 73, 3222-3230.

Ho, T.T., Ngo, V.M. \& Preston, T.R., 2008. Estimates of protein fractions of various heat-treated feeds in ruminant production. Livest. Res. Rural. Dev. 20, 1-11.

Hsu, J.T. \& Satter, L.D., 1995. Procedures for measuring the quality of heat-treated soybeans. J. Dairy Sci. 78, 13531361.

Kafilzadeh, F., SahebiAla, M. \& Heidary, N., 2013. The effect of physical and chemical treatments of canola seed varieties on crude protein fractions using CNCPS and in vitro. J. Agr. Sci. Technol. 9, 1411-1421.

Licitra, C., Hernandez, T.N. \& Van Soest, P.J., 1996. Standardization of procedures for nitrogen fractionation of ruminant feeds. Anim. Feed Sci. Technol. 57, 347-358.

Lin, C. \& Kung, L., 1999. Heat treated soybeans and soybean meal in ruminant nutrition. Technical Bull. American Soybean Assoc. and United Soybean Board. pp. 1-18.

Ljukjel, K., Harstad, O.M. \& Skrede, A., 2000. Effect of heat treatment of soybean meal and fish meal on amino acid digestibility in mink and dairy cows. Anim. Feed Sci. Technol. 84, 83-95.

McAllister, T.A., Cheng, K.J., Beauchemin, K.A., Bailey, D.R.C., Pickard, M.D. \& Gilbert, R.P., 1993. Use of lignosulfonate to decrease the rumen degradability of canola meal protein. Can. J. Anim. Sci. 73, 211-215.

McKinnon, J.J., Olubobokun, J.A., Mustafa, A. \& Cohen, R.D.H., Christensen, D.A., 1995. Influence of dry heat treatment of canola meal on site and extent of nutrient disappearance in ruminants. Anim. Feed Sci. Technol. $56,243-252$.

Moshtaghi Nia, S.A. \& Ingalls, J.R., 1992. Effect of heating on canola meal protein degradation in the rumen and digestion in the lower gastrointestinal tract of steers. Can. J. Anim. Sci. 72, 83-88.

Mustafa, A.F., McKinnon, J.J. \& Christensen, D.A., 1999. Effect of moist heat treatment on in vitro degradability and ruminal escape protein and amino acids of mustard meal. Anim. Feed Sci. Technol. 76, 265-274. 
Mustafa, A.F., Christensen, D.A., McKinnon, J.J. \& Newkirk, R., 2000. Effects of stage of processing of canola seed on chemical composition and in vitro protein degradability of canola meal and intermediate products. Can. J. Anim. Sci. 80, 211-214.

Mustafa, A.F., Chouinard, Y.P., Ouellet, D.R. \& Soita, H., 2003. Effects of moist heat treatment on ruminal nutrient degradability of sunflower seed. J. Sci. Food Agric. 83, 1059-1064.

NRC, 2001. Nutrient Requirements of Dairy Cattle (7th ed). National Academy Press, Washington D.C., USA.

Palic, D., Modika, K.Y., Oelofse, A., Morey, L. \& Coetzee, S.E., 2011. The protein dispersibility index in the quality control of heat-treated full-fat soybeans: An inter-laboratory study. S. Afr. J. Anim. Sci. 41, 413-419.

Petit, H.V., Tremblay, G.F., Marcotte, M. \& Audy, R., 1999. Degradability and digestibility of full-fat soybeans treated with different sugar and heat combinations. Can. J. Anim. Sci. 79, 213-220.

Petit, H.V., Tremblay, G.F., Tremblay, E. \& Nadeau, P., 2002. Ruminal biohydrogenation of fatty acids, protein degradability, and dry matter digestibility of flaxseed treated with different sugar and heat combinations. Can. J. Anim. Sci. 82, 241-250.

Pichard, G. \& Van Soest, P.J., 1977. Protein solubility of ruminant feeds. Proc. Cornell Nutr. Conf. p. 91.

Reddy, P.V., Morrill, J.L. \& Bates, L.S., 1993. Effect of roasting temperatures on soybean utilization by young dairy calves. J. Dairy Sci. 76, 1387-1393.

SAS, 2001. Statistical Analysis Systems user's guide (Version 9.1.). SAS Institute Inc., Raleigh, North Carolina, USA.

Satter, L.D., Hsu, J.T. \& Dhiman, T.R., 1993. Evaluating the quality of roasted soybeans. Proc. Advanced Nutr. Seminar for Feed Prof. Wisconsin Ext., Madison, WI., USA.

Schwab, C.G., Tylutki, T.P., Ordway, R.S., Sheaffer, C. \& Stern, M.D., 2003. Characterization of proteins in feeds. J. Dairy Sci. 86, (E. Suppl.), E88-E103.

Sniffen, C.J., O'Connor, J.D., Fox, D.G. \& Russell, J.B., 1992. A net carbohydrate and protein system for evaluating cattle diets: II. Carbohydrate and protein availability. J. Anim. Sci. 70, 3562-3577.

Socha, M., 1991. Effect of feeding heat-processed whole soybeans on milk production, milk composition, and milk fatty acid profile. M.S. Thesis, Univ. Wisconsin, USA.

Van Soest, P.J., 1994. Nutritional Ecology of the Ruminant. 2nd ed., Cornell University Press, Ithaca, NY. pp. 476.

Van Soest, P.J., Robertson, J.B. \& Lewis, B.A., 1991. Methods for dietary fiber neutral detergent fiber and no starch polysaccharides in relation to animal nutrition. J. Dairy Sci. 74, 3583-3597.

Yu, P., 2005. Protein secondary structures (a-helix and ß-sheet) at a cellular level and protein fractions in relation to rumen degradation behaviours of protein: A new approach. Br. J. Nutr. 94, 655-665.

Zhu, S., Riaz, M.N. \& Lusas, E.W., 1996. Effect of different extrusion temperatures and moisture content on lipoxygenase inactivation and protein solubility in soybeans. J. Agric. Food Chem. 44, 3315-3318. 